\title{
Literature Study of Convolutional Neural Network Algorithm for Batik Classification
}

\author{
Nardianti Dewi Girsang ${ }^{1 *}$ \\ ${ }^{1}$ Universitas Medan Area, Indonesia \\ ${ }^{1}$ nardiantidewigirsang@g,gmail.com
}

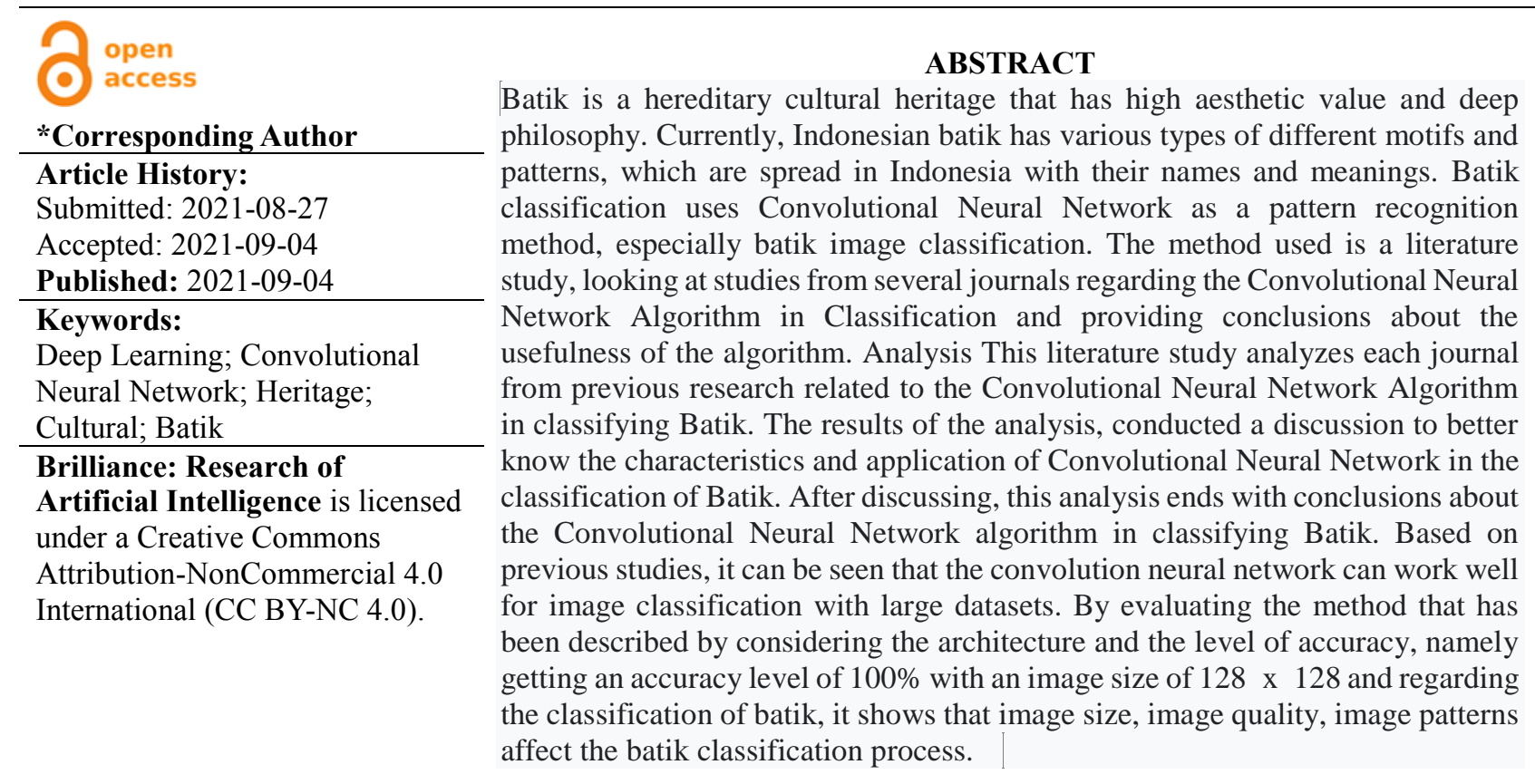

\section{INTRODUCTION}

Batik is one of the cultural icons from Indonesia that has received an award as a cultural heritage from UNESCO on October 2, 2009. Based on the field of fine arts, batik is a two-dimensional painting, in which cloth is the painting medium. Batik has a high value and charisma. Various kinds of batik motifs have been produced from generation to generation, where the motif contains the meaning of the ancestors who have animism and dynamism (Girsang \& Muhathir, 2021). In another sense, batik is a form of visual art from Indonesia which is produced using traditional drawing techniques on materials. For the Javanese, batik is a traditional cloth that is integral to their cultural identity. Currently, there are hundreds of batik cloth motifs scattered in Indonesia which sometimes have their names and meanings. The motif of batik is based on the shape and pattern of the painting depicted. The number of batik patterns in Indonesia makes it difficult to identify motifs, especially for ordinary people. The existence of a method to facilitate the introduction of batik patterns certainly has many benefits. One method that can be used is to classify images in computer-based batik by utilizing artificial intelligence (Mawan, 2020).

Artificial intelligence has been studied by philosophers for years. This makes Artificial Intelligence (AI) try to build intelligent entities that are following human understanding. Artificial intelligence is a branch of computer science that covers a fairly large field of science, one of which is machine learning (Prahartiningsyah \& Kurniawan, 2021). Machine learning is a method used to create programs that can learn from data. Where machine learning is an implementation of AI. Machine learning itself focuses on developing computer programs that can teach themselves to grow and change when given new data (Qudsi, Asmara, \& Syulistyo, 2019).

Pattern recognition is a process for retrieving and classifying data, where the data can be in the form of images, writing, sounds, numbers, and others. Pattern recognition is one of the fields that focuses on the method of classifying objects into certain classes to solve certain problems. Pattern recognition also has several kinds of processes, namely, image retrieval, preprocessing used to remove noise, feature extraction, and classification. Thus, pattern recognition is widely used as data classification (Umam \& Handoko, 2020).

Classification can be used in several fields such as machine learning, deep learning, and artificial intelligence. The trend in deep learning has increased in the last 10 years. Therefore, the use of classification in deep learning is expected to find high accuracy/results. The classification process cannot be separated from the data used, either in the form of text or images (image processing). However, if you use image processing, there are image dimensions. According to the 
$\mathrm{KBBI}$, dimension is a measure that includes length, area, height, width, and so on. Therefore it is necessary to research whether the dimensions affect the classification process (Kusrini, Mawan, \& Fatta, 2020)

Deep Learning is part of Machine Learning which consists of many layers (hidden layer) and forms a stack, the layer is an algorithm or method that performs the classification of inputted commands to produce output. One of the developing Deep Learning methods is the Convolutional Neural Network. This network uses input in the form of an image, then it will go through a convolution layer and be processed based on the specified filter, each layer produces a pattern from several parts of the image that facilitates the classification process (Nurfita \& Ariyanto, 2018).

Convolutional Neural Network is an algorithm that has become popular since the ImageNet 2012 classification benchmark competition. Until now, $\mathrm{CNN}$ has been the choice for methods that use image data as input because of its good performance. Several introductions related to writing recognition have been carried out with average accuracy results obtained above 80\% (Pradhana, Untari Novia Wisesty S.T., \& Febryanthi Sthevanie S.T., 2020). Convolutional Neural Network (CNN) is one of the advanced algorithms owned by the neural network and has a good model class for recognizing handwritten text. The neural network works like the human brain, which can be trained to increase its knowledge to get high accuracy. By analyzing each image pixel and matching it with existing data, this method is suitable for damaged documents and text. Neural networks are ideal for specific problems such as stock market data or finding trending image patterns, so far the neural network is the most efficient method compared to other methods (Susilo, Wonohadidjojo, \& Sugianto, 2017).

Convolutional Neural Network (CNN) or commonly called ConvNet, CNN extracts features from input in the form of images and then changes the dimensions of the image to be smaller without changing the characteristics of the image. CNN consists of neurons that have weights and biases. Each neuron receives input and is forwarded by doing a dot multiplication on each of these neurons. In the last layer, CNN still has a loss function like SVM/Softmax. By using an image sensor such as a camera, the effort used to prepare the device is much easier, for example, as almost everyone now has a camera device on a smartphone (Ersyad, Ramadhani, \& Arifianto, 2020). Convolutional neural network algorithms are very popular among deep learning because the most important factor is in terms of eliminating feature extraction that can be trained according to the suitability of the task to recognize new objects that are likely to build an existing network. In addition, CNN has several other models, namely CNN with 1 conventional layer, CNN with 2 layers, CNN with 3 layers, and CNN with 4 layers (Omori \& Shima, 2020).

Batik classification uses Convolutional Neural Network as a pattern recognition method, especially batik image classification. The Convolutional Neural Network (CNN) method uses a deep learning model which can carry out an independent learning process for object recognition, object extraction, and classification and can be applied to highresolution images that have a nonparametric distribution model. The application of the CNN method is used to recognize batik patterns. Classification using Convolutional Neural Network Algorithm. The method used is a literature study, looking at studies from several journals regarding the Convolutional Neural Network Algorithm in Classification and providing conclusions about the usefulness of the algorithm.

\section{LITERATURE REVIEW}

Several studies have been conducted using the Convolutional Neural Network Algorithm method which has been applied to batik classification research. In a study (Maulida, 2021) that discusses the Classification of Typical Batik Fabrics and Sasirangan Typical Fabrics Using the Convolutional Neural Network Method, it was found that this study resulted in the CNN method having two stages, namely, image classification with feed-forward and carrying out learning stages which were at the learning stage. CNN applies the backpropagation method. The classification process carried out must go through a preprocessing which applies wrapping and cropping methods intending to focus objects to be classified. Then do the training using the feed-forward and backpropagation methods. And the final stage is the classification stage by applying the feedforward method whose weight and bias values have been updated. After doing these results, the results obtained an accuracy of $91.84 \%$ when trained by conducting random data with 20 epochs and when testing data with 10 random data, the accuracy results obtained as much as $99.73 \%$.

In a study (Fonda, Irawan, \& Febriani, 2020) that discussed the Classification of Riau Batik by Using the Convolutional Neural Network, it was found that this study produced Riau batik and not Riau batik with an accuracy of $65 \%$. The accuracy of $65 \%$ is because many of the motifs are the same between Riau batik and other batiks, with the difference being in the color of the cerap in Riau batik.

In a study (Bowo, Syaputra, \& Akbar, 2020) that discusses the application of the Convolutional Neural Network Algorithm for Classification of Solo Batik Image Motifs, it was found that this research resulted in the creation of a data classification model for the image of solo batik motifs that had been successfully carried out using a deep learning method with Convolutional architecture. Neural Network (CNN). The CNN model in this study uses an input shape measuring $32 \times 32 \times 3$, filter size $3 \times 3$, the number of epochs is 100 . The data used for the model training process is 2256 resulting in an accuracy level of training and testing in detecting images of batik solo images of $99 \%$ for accuracy and $94 \%$ for accuracy validation. This study uses new testing data of 745 images where per class there are 96 to 127 images to be 
tested into the model that has been made. The results of the testing resulted in a new level of accuracy in classifying the motifs of the solo batik image, which was $95 \%$.

\section{METHOD}

The method related to this analysis, Study literature is a review of related literature. Therefore, the literature review serves as a review of the literature (research reports, etc.) on related issues, which do not always have to be identical to the problem area at hand but also include those that are frequent and related. Analysis This literature study analyzes each journal from previous research related to the Convolutional Neural Network Algorithm in classifying Batik. The results of the analysis, conducted a discussion to better know the characteristics and application of Convolutional Neural Network in the classification of Batik. After discussing, this analysis ends with conclusions about the Convolutional Neural Network algorithm in classifying Batik.

The system designed to solve batik images in solving classification problems uses Convolutional Neural Network (CNN). The batik image classification system offered in this research has a design with two phases, the first is the training phase, this phase is system training to get the model used to classify the image and the second is the testing phase, this phase is used to test the trained model. using new data outside of training data. In the training phase, the data and class labels are used as input in the proposed CNN system. From the results of the training, a classification model will be obtained that will be used in the testing phase. Testing data is used as input into the model and class predictions are obtained. The research method is a research procedure and technique. Between one study and another, the procedures and techniques will differ.

Broadly speaking, the classification process using the CNN Algorithm starts from collecting data in the field. The data is used as a dataset for the training and testing process. The preprocessing process is then carried out by designing the CNN Algorithm model and followed by testing the model. After the model is tested, the accuracy will be obtained. The final stage is to test the CNN algorithm using the Confusion Matrix (Ihsan, 2021).

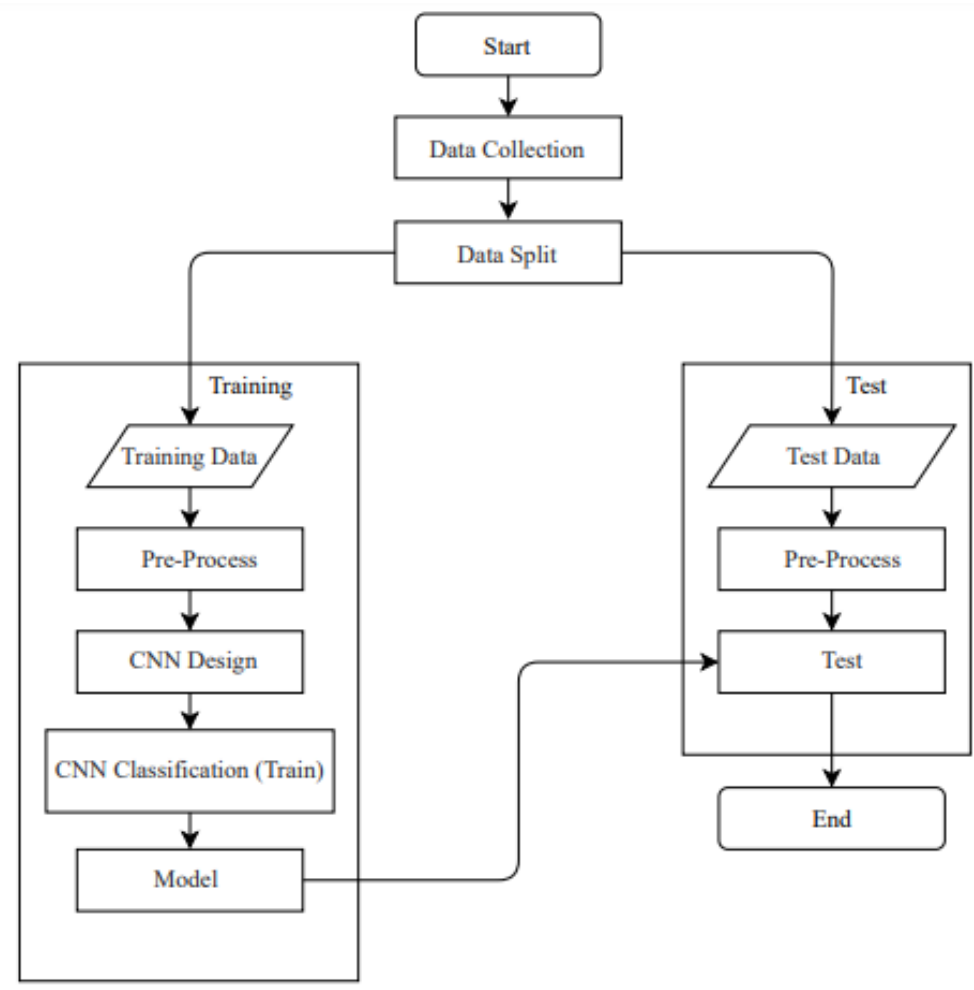

Fig. 1 Classification Process Using CNN

\section{Data Collection}

The data collection method used to obtain the image of batik is by retrieving/downloading via google, or taking data directly. From this data, samples were taken to be used as training data and test data. 


\section{Data Split}

The data collected is then divided into two parts, namely test data and training data, each of which has two classification classes, namely normal data classification and abnormal data with a certain percentage. The test data will be used in the model training process while the training data will be used in the testing process after the model is formed. Pre-Process

Before conducting training, the data must first be processed or prepared, the data is prepared by changing the size of the data to pixel size and converting the image to grayscale because the classification will focus on the shape of the data, not on the color of the data, this process is also useful for reducing the learning load during the training process done.

\section{CNN Design}

In this process, it is determined the number of layers used, the type of activation, the number of batches, the number of epochs, the size of the convolution, the size of the pooling, and several other parameters needed.

\section{CNN Classification (Train)}

In this process, the prepared data will be used to perform with a predetermined class, namely normal data and abnormal data, and will produce a model. This model will then be used in testing and if it proves good it can be implemented.

\section{Test}

This process will test the model that has been previously generated and then tested with the test data that has been prepared. This test data will represent new data that will be generated by the system aiming to check the level of accuracy in the actual implementation. The final stage is testing the CNN algorithm using the Confusion Matrix.

\section{RESULT}

The dataset used in this study is a dataset of batik images collected from various sources, such as offline stores and batik craftsmen, as well as from online stores and online search engines. The collected dataset is then converted into an image in jpg format. This data is divided into two classes, namely the abnormal data class and the normal data class. Abnormal data and normal data are presented in visual form to make it easier for users to read the information that has been processed from data obtained from batik. Next is Data Processing. Training is carried out using training data for normal data classes and data for abnormal data classes. This data will then be split back into $70 \%$ for training and $30 \%$ for validation. The training will use 2 convolutions with a size of $3 \times 3$ and a pooling of 2x2, a layer with ReLU (Rectified Linear Unit) as the activation function, 10 epochs with a batch size of 16. Different epochs will result in different accuracy and loss. Next is testing, the model that has been built previously will be tested with test data to see its accuracy.

Table 1

Convolutional Neural Network Study Literature Results

\begin{tabular}{|c|c|c|c|c|}
\hline Writer & Title & Architecture & Image size & Accuracy \\
\hline $\begin{array}{l}\text { (Wicaksono, } \\
\text { Suciati, } \\
\text { Fatichah, } \\
\text { Uchimura, \& } \\
\text { Koutaki, } \\
\text { 2017) }\end{array}$ & $\begin{array}{l}\text { Modified Convolutional } \\
\text { Neural Network } \\
\text { Architecture for Batik } \\
\text { Motif Image } \\
\text { Classification }\end{array}$ & CNN IncRes Network & $256 \times 256$ & $70,84 \%$ \\
\hline $\begin{array}{l}\text { (Rasyidi \& } \\
\text { Bariyah, } \\
\text { 2020) }\end{array}$ & $\begin{array}{l}\text { Batik pattern recognition } \\
\text { using convolutional } \\
\text { neural network }\end{array}$ & CNN DenseNet Network & - & $94 \%$ and $99 \%$ \\
\hline $\begin{array}{l}\text { (Handayani, } \\
\text { Rasyidi, \& } \\
\text { Aziz, 2021) }\end{array}$ & $\begin{array}{l}\text { Identification of batik } \\
\text { making method from } \\
\text { images using a } \\
\text { convolutional neural } \\
\text { network with a limited } \\
\text { amount of data }\end{array}$ & $\begin{array}{l}\text { ResNet, DenseNet, and VGG } \\
\text { Networks }\end{array}$ & $540 \times 630$ & $\begin{array}{c}79.17 \% \text { and } \\
87.61 \%\end{array}$ \\
\hline
\end{tabular}




\begin{tabular}{|c|c|c|c|c|}
\hline $\begin{array}{l}\text { (Tristanto, } \\
\text { Hendryli, \& }\end{array}$ & $\begin{array}{l}\text { Classification of Batik } \\
\text { Motifs Using }\end{array}$ & $\mathrm{CNN}$ & $160 \times 160$ & $\begin{array}{c}56 \%, 91,67 \%, \\
\text { dan } 40-60 \%\end{array}$ \\
\hline $\begin{array}{l}\text { Herwindiati, } \\
\text { 2018) }\end{array}$ & $\begin{array}{l}\text { Convolutional Neural } \\
\text { Networks }\end{array}$ & & & \\
\hline $\begin{array}{l}\text { (Azhar, } \\
\text { Mustaqim, } \\
\text { \& Minarno, } \\
\text { 2020) }\end{array}$ & $\begin{array}{l}\text { Ensemble convolutional } \\
\text { neural network for robust } \\
\text { batik classification }\end{array}$ & $\begin{array}{l}\text { Convolutional layers, alternating } \\
\text { dropout, and max-pooling } \\
\text { layers. Classification with } 3 \\
\text { (three) fully connected layers } \\
\text { and combined with the ensemble } \\
\text { methods. }\end{array}$ & $128 \times 128$ & $100 \%$ \\
\hline $\begin{array}{l}\text { (Negara, } \\
\text { Satria, } \\
\text { Sanjaya, \& } \\
\text { Santoso, } \\
\text { 2021) }\end{array}$ & $\begin{array}{l}\text { ResNet-50 for } \\
\text { Classifying Indonesian } \\
\text { Batik with Data } \\
\text { Augmentation }\end{array}$ & ResNet-50 & - & $96 \%$ \\
\hline
\end{tabular}

Table 2

Results of Study Literature Classification of Batik

\begin{tabular}{|c|c|c|c|c|}
\hline Writer & Title & Purpose Of Paper & Conclusion & Suggestion \\
\hline $\begin{array}{l}\text { (Puarungroj \& } \\
\text { Boonsirisumpun, } \\
\text { 2019) }\end{array}$ & $\begin{array}{l}\text { Convolutional } \\
\text { Neural Network } \\
\text { Models for } \\
\text { HandWoven } \\
\text { Fabric Motif } \\
\text { Recognition }\end{array}$ & $\begin{array}{l}\text { To automate Motive } \\
\text { Recognition }\end{array}$ & $\begin{array}{l}\text { The results show that } \\
\text { MobileNets outperformed } \\
\text { Inception-v3 with an } \\
\text { accuracy rate of } 98.223 \% \text { and } \\
93.208 \% \text {, respectively. }\end{array}$ & - \\
\hline $\begin{array}{l}\text { (Khasanah, } \\
\text { Utami, \& } \\
\text { Raharjo, 2020) }\end{array}$ & $\begin{array}{l}\text { Implementation } \\
\text { of Data } \\
\text { Augmentation } \\
\text { Using } \\
\text { Convolutional } \\
\text { Neural Network } \\
\text { for Batik } \\
\text { Classification }\end{array}$ & $\begin{array}{l}\text { Applying } 8 \text { types of } \\
\text { data augmentation to } \\
\text { the batik dataset using } \\
\text { the VGG16 pre- } \\
\text { training model with the } \\
\text { Fine-tuning method. }\end{array}$ & $\begin{array}{l}\text { Batik classification with the } \\
\text { selection of data } \\
\text { augmentation succeeded in } \\
\text { increasing the accuracy by } \\
3.13 \% \text { from } 95.83 \% \text { (without } \\
\text { data augmentation) to } 98.96 \% \\
\text { (with the selection of data } \\
\text { augmentation). }\end{array}$ & - \\
\hline $\begin{array}{l}\text { (Prasetyo \& } \\
\text { Akardihas, } \\
\text { 2019) }\end{array}$ & $\begin{array}{l}\text { Batik Image } \\
\text { Retrieval Using } \\
\text { Convolutional } \\
\text { Neural Network }\end{array}$ & $\begin{array}{l}\text { The use of } \\
\text { convolutional neural } \\
\text { networks to carry out } \\
\text { CBIR tasks to solve } \\
\text { problems that occur in } \\
\text { batik image retrieval. }\end{array}$ & $\begin{array}{l}\text { This system achieves retrieval } \\
\text { accuracy of } 99.47 \% \text { and } \\
76.54 \% \text {, respectively, while } \\
\text { the image features are built } \\
\text { from deep learning } \\
\text { architecture based on CNN } \\
\text { and CAE on the Batik image } \\
\text { database. }\end{array}$ & - \\
\hline $\begin{array}{l}\text { (Widyantoko, } \\
\text { Widowati, } \\
\text { Isnaini, \& } \\
\text { Trapsiladi, 2021) }\end{array}$ & $\begin{array}{l}\text { Expert role in } \\
\text { image } \\
\text { classification } \\
\text { using CNN for } \\
\text { hard to identify } \\
\text { object: }\end{array}$ & $\begin{array}{l}\text { Identifying Batik and } \\
\text { its imitations. And } \\
\text { compare two popular } \\
\text { CNN models to } \\
\text { classify batik products } \\
\text { into five classes }\end{array}$ & $\begin{array}{l}\text { Accuracy results show that } \\
\text { models trained with image- } \\
\text { based suggestions perform } \\
\text { better than those trained with } \\
\text { randomized images. }\end{array}$ & - \\
\hline
\end{tabular}


distinguishing

batik and its

imitation

(Agastya \&

Setyanto, 2018)

(Handhayani,

Hendryli, \&

Hiryanto, 2017)

(Mardani,

Pranowo, \&

Santoso, 2020)

(Minarno, 2021)

Classification of
Batik Types
Using the
Convolutional
Neural Network
Algorithm

\begin{abstract}
Deep learning for recognition of Javanese batik patterns
\end{abstract}

\section{Classification of Indonesian \\ Batik Using \\ Deep Learning \\ Techniques and \\ Data \\ Augmentation}

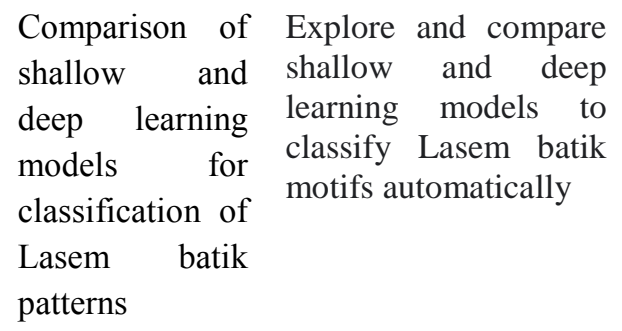

To recognize batik patterns automatically using the Convolutional Neural Network (CNN) called VGG-16 and VGG-19

The classifier can give good results because the split image dataset is enough to make the classifier understand the important features of the batik dataset.

Shallow models, particularly supporting vector machines with linear function kernels perform best, even compared to deep learning models.
Classification of batik motif images
The test results using crossvalidation can achieve an accuracy of $90.14 \%$. So from the test results, it can be concluded that deep learning using the CNN method can be used to classify batik motifs well.

To prove the proposed model can classify batik images well.
It can be proven that the accuracy obtained using CNN is $98 \%$ and requires faster time than the VGG16 model.

\section{DISCUSSION}

Based on previous studies, it can be seen that the convolutional neural network can work well for classifying images with large datasets. After conducting this literature study, further research can use other cases. Like the classification of the Simalungun Shark, which currently many people do not recognize the type of Shark.

\section{CONCLUSION}

The study included in this system shows that the literature on this argument is focused mainly on the Classification of batik and Convolutional Neural Networks, the main idea of this method is to use Convolutional Neural Network to identify batik. By evaluating the method that has been described by considering the architecture and the level of accuracy, namely getting an accuracy level of 100\% with an image size of 128x128 and regarding the classification of batik, it shows that image size, image quality, image patterns affect the batik classification process.

\section{REFERENCES}

Agastya, I. M., \& Setyanto, A. (2018). Classification Of Indonesian Batik Using Deep Learning Techniques And Data Augmentation. International Conference On Information Technology, Information System And Electrical Engineering (Icitisee), 27-31.

Azhar, Y., Mustaqim, M. C., \& Minarno, A. E. (2020). Ensemble Convolutional Neural Network For Robust Batik. Top Conference Series: Materials Science And Engineering, 1-9.

Bowo, T. A., Syaputra, H., \& Akbar, M. (2020). Penerapan Algoritma Convolutional Neural Network Untuk Klasifikasi 
Motif Citra Batik Solo. Journal Of Software Engineering Ampera, 82-96.

Ersyad, M. Z., Ramadhani, K. N., \& Arifianto, A. (2020). Pengenalan Bentuk Tangan Dengan Convolutional Neural Network (Cnn). E-Proceeding Of Engineering, 8212-8222.

Fonda, H., Irawan, Y., \& Febriani, A. (2020). Klasifikasi Batik Riau Dengan Menggunakan Convolutional Neural Networks (Cnn). Jurnal Ilmu Komputer, 7-10.

Girsang, N. D., \& Muhathir. (2021). Classification Of Batik Images Using Multilayer Perceptron With Histogram Of Oriented Gradient Feature Extraction. Proc. Internat. Conf. Sci. Engin. 3, 197-204.

Handayani, R., Rasyidi, M. A., \& Aziz, F. (2021). Identification Of Batik Making Method From Images Using Convolutional Neural Network With Limited Amount Of Data. Bulletin Of Electrical Engineering And Informatics, 1300 1307.

Handhayani, T., Hendryli, J., \& Hiryanto, L. (2017). Comparison Of Shallow And Deep Learning Models For Classification Of Lasem Batik Patterns. International Conference On Informatics And Computational Sciences (Icicos), 11-16.

Ihsan, C. N. (2021). Klasifikasi Data Radar Menggunakan Algoritma Convolutional Neural Network. Journal Of Computer And Information Technology, 115-121.

Khasanah, C. U., Utami, E., \& Raharjo, S. (2020). Implementation Of Data Augmentation Using Convolutional Neural Network For Batik Classification. International Conference On Cyber And It Service Management (Citsm), 1-5.

Kusrini, Mawan, R., \& Fatta, H. A. (2020). Pengaruh Dimensi Gambar Pada Klasifikasi Motif Batik Menggunakan Convolutional Neural Network. Jurnal Teknologi Informasi, 218-223.

Mardani, D. A., Pranowo, \& Santoso, A. J. (2020). Deep Learning For Recognition Of Javanese Batik Patterns. Aip Conference Proceedings.

Maulida, I. (2021). Klasifikasi Kain Khas Batik Dan Kain Khas Sasirangan Dengan Menggunakan Metode Convolutional Neural Network. Jtiulm, 25-30.

Mawan, R. (2020). Klasifikasi Motif Batik Menggunakan Convolutionalneural Network . Jnanaloka, 45-50.

Minarno, A. E. (2021). Klasifikasi Jenis Batik Menggunakan Algoritma Convolutional Neural Network. Repositor.

Negara, B. S., Satria, E., Sanjaya, S., \& Santoso, D. R. (2021). Resnet-50 For Classifying Indonesian Batik With Data Augmentation. International Congress Of Advanced Technology And Engineering (Icoten), 1-4.

Nurfita, R. D., \& Ariyanto, G. (2018). Implementasi Deep Learning Berbasis Tensorflow Untuk Pengenalan Sidik Jari. Jurnal Teknik Elektro, 22-27.

Omori, Y., \& Shima, Y. (2020). Image Augmentation For Eye Contact Detection Based On Combination Of Pre-Trained Alex-Net Cnn And Svm. Journal Of Computers, 85-97.

Pradhana, S. C., Untari Novia Wisesty S.T., M., \& Febryanthi Sthevanie S.T., M. (2020). Pengenalan Aksara Jawa Dengan Menggunakan Algoritma Convolutional Neural Network. E-Proceeding Of Engineering, 2558-2567.

Prahartiningsyah, A. A., \& Kurniawan, T. B. (2021). Pengenalan Pola Angka Menggunakan Pendekatan Optimisasi Sistem Kekebalan Buatan (Artificial Immune System). Jurnal Media Informatika Budidarma, 856-865.

Prasetyo, H., \& Akardihas, B. A. (2019). Batik Image Retrieval Using Convolutional Neural Network. Telkomnika, 30103018.

Puarungroj, W., \& Boonsirisumpun, N. (2019). Convolutional Neural Network Models For Handwoven Fabric Motif Recognition. Ecti Damt-Ncon, 300-303.

Qudsi, N. K., Asmara, R. A., \& Syulistyo, A. R. (2019). Identifikasi Citra Tulisan Tangan Digital Menggunakan Convolutional Neural Network (Cnn). Seminar Informatika Aplikatif Polinema, 48-53.

Rasyidi, M. A., \& Bariyah, T. (2020). Batik Pattern Recognition Using Convolutional Neural Network. Bulletin Of Electrical Engineering And Informatics, 1430-1437.

Susilo, M. M., Wonohadidjojo, D. M., \& Sugianto, N. (2017). Pengenalan Pola Karakter Bahasa Jepang Hiragana Menggunakan 2d Convolutional Neural Network. Juisi, 28-36.

Tristanto, J., Hendryli, J., \& Herwindiati, D. E. (2018). Classification Of Batik Motifs Using Convolutional Neural Networks. International Conference On Information Technology, Engineering, Science, And Its Applications, 15.

Umam, C., \& Handoko, L. B. (2020). Convolutional Neural Network (Cnn) For Hiragana Character Identification. Semnas Lppm, 527-533.

Wicaksono, A. Y., Suciati, N., Fatichah, C., Uchimura, K., \& Koutaki, G. (2017). Modified Convolutional Neural Network Architecture For Batik Motif Image Classification . Journal Of Science, 26-30.

Widyantoko, Z., Widowati, T. P., Isnaini, \& Trapsiladi, P. (2021). Expert Role In Image Classification Using Cnn For Hard To Identify Object: Distinguishing Batik And Its Imitation. Iaes International Journal Of Artificial Intelligence, 93-100.

Yohannes, \& Rivan, M. E. (2020). Penggunaan Global Contrast Saliencydan Histogram Of Oriented Gradientsebagai Fitur Untuk Klasifikasi Jenis Hewan Mamalia. Petir, 13, 80-85. 